Comm. in Asteroseismology

Vol. 152, 2008

\title{
BRITE-Austria/TUG Sat1: Project Overview
}

\author{
O. Koudelka ${ }^{1}$
}

${ }^{1}$ Institut für Kommunikationsnetze und Satellitenkommunikation, Universität Graz, Inffeldgasse 12,8010 Graz, Austria

\section{Abstract}

This proceeding paper was generated using a Power-Point presentation from the workshop.

Presentation Slides

\section{PLANNED SATELLITE PROJECTS (1)}

- GRAZIJA:

- Small scientific sub-satellite to be released from MIR Space Station during AUSTROMIR mission 1991

- nicht realised to due time constraints

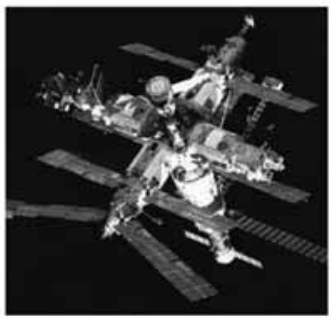




\section{PLANNED SATELLITE PROJECTS (2)}

\section{- ALPSAT:}

- Cooperation Switzerland / Austria

- Very challenging mission, satellite positioned at Lagrange-Point

- Not realised due to budget constraints

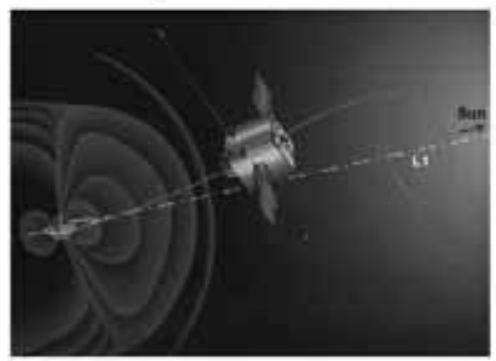

\section{PROJECT IDEAS}

- Workshops for potential small satellite missions

- Indication by FFG/ALR for support of a small satellite project

- CUBESAT studies by TU Graz

- BRITE proposal by UTIAS and Univ. of Vienna

- Joint proposal by TUG, UV, TUW submitted to FFG/ALR in September 2005 


\section{TUG SAT-1 /BRITE AUSTRIA}

- Design, Development, Construction, Test, Launch and Operations of the first Austrian Satellite

- Finaned within framework of Austrian National Space Program by Austrian Science Promotion Agency (FFG)

- Training of students

- Hands-on experience in conduct of a challenging space projects

- Synergies between several scientfic fields

- Electrical engineering and telematics

- Astronomy

- Mechanical engineering and thermodynamics

- Satellite geodesy

\section{BRITE AUSTRIA - The Partners}

- Ministry of Transport, Innovation and Transport

- National Space Programm

- Science Promotion Agency FFG/ALR

- Initiator of the project

- Operations of the national Space Program

- TU Graz (Prof.O.Koudelka)

- Project Management TUGSAT-1/BRITE-AUSTRIA

- System studies, building/testing of TUGSAT-1/BRITE-AUSTRIA

- Launch, operations of Graz station

- University of Vienna Wien (Prof.W.Weiss)

$$
\text { Astronomy, Science Cooperation }
$$

- TU Wien (Prof.A.Scholtz)

- Operations of Vienna Ground Station

- Space Flight Labortory, University of Toronto

- Design

- Delivery of key components

$$
\text { Wiversität TU }
$$




\section{TUG SAT-1 / BRITE AUSTRIA Bright Target Explorer}

- Scientific Goal: Investigation of massive luminous stars with precise star camera

- Opens up new dimension for astronomers

- Observation of stars without interference of earth atmosphere

- With small low-cost spacecraft

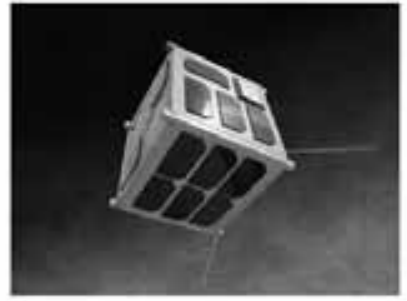

\section{SCIENTIFIC GOAL}

- Measurement of oscillation of luminous stars

(magnitude +3.5)

- Recording of time-series (minutes to months)

\section{SATELLITE CONSTELLATION}

- Pair of satellites:

- Different spectral filters (red and blue)

- Colour information in addition to brightness

- No moving parts

- Longer observation times

- Minimisation of risk

- Reduction of development costs 


\section{INSTRUMENT}

- Telescope with CCD sensors

- Simultaneous observation of several stars

- Differential photometry

- Nominal exposure time 15 Minuten (orbit duration 100 minutes)

- Sequences of $>100$ days

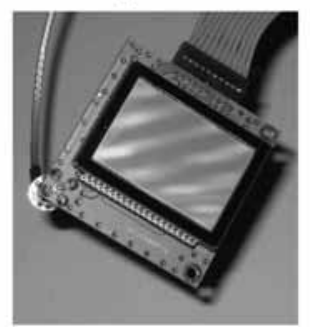

\section{TUG SAT-1 / BRITE-AUSTRIA}

- „Nanosatellite“

- Mass: approx. $6 \mathrm{~kg}$

- Innovation: precise three-axis stabilisation

- Arcminute level

- Nano momentum wheels

- Attitude control computer

- Coarse and fine sun sensors

- Magnetometer

- Magnetorquer

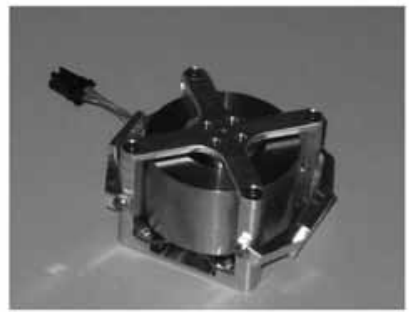




\section{TECHNICAL DATA}

- Power supply: $6 \mathrm{~W}$ (solar cells)

- Data rate: 32 kbit/s (min.), 256 kbit/s (max.)

- Data volume/ day: typ. 2 MByte

- Frequencies:

- 2234.4 MHz (S-Band downlink)

- $437.365 \mathrm{MHz}$ (UHF uplink)

- $145.89 \mathrm{MHz}$ (VHF beacon)

- Transmit power:

- $0.5 \mathrm{~W}$ (for S-band downlink)

- $0.1 \mathrm{~W}$ (for VHF beacon)

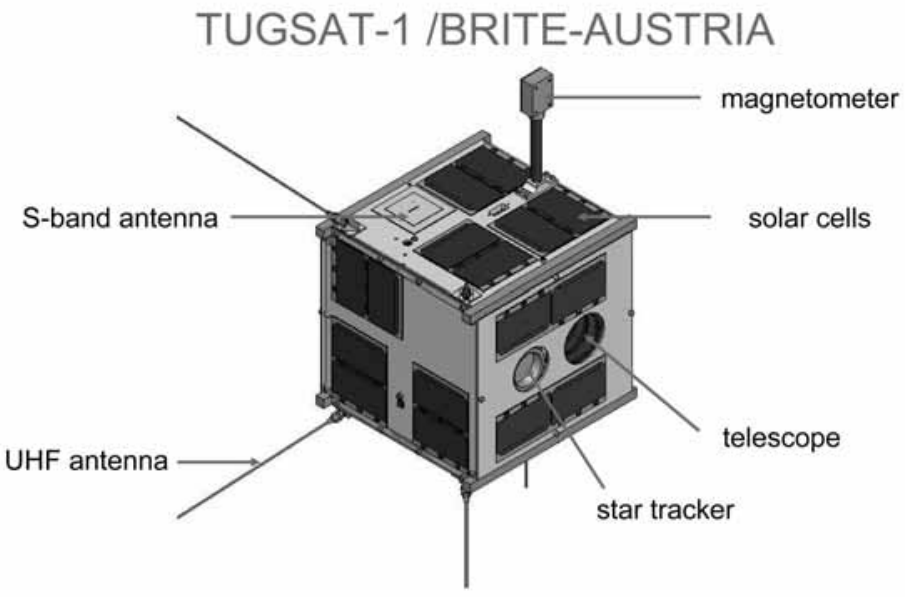




\section{ORBIT}

- Sun-synchronous or polar orbit

- Approx. 800 km

\section{COSTS / TIME PLAN}

- Development and testing: 2 years

- Costs for development: $450 \mathrm{k} €(\mathrm{FFG} / \mathrm{ALR})+50 \mathrm{k} €$ for ground station Graz (TUG)

- First part of Phase 2: $250 \mathrm{k} €$

- Launch opportunities

- Software development (ground support and science software)

- Mission duration: min. 2 years

\section{STATUS}

- PDR in October 2007

- CDR before summer 2007

- Building starts in summer

- Completion of spacecraft by Q3/2008

- Launch planned for end 2008 / begin 2009 


\section{SUMMARY}

- Challenging scientific and technological mission

- Sustainability: development of a cost-efficient satellite platform for future missions

- Added value for education:

- Training for students

- Young engineers and scientists

- Raising interest of the public for space research and technology

\section{INFORMATION}

\section{www.iks.tugraz.at www.tugsat.at}

Kontakt: tugsat1@iks.tugraz.at

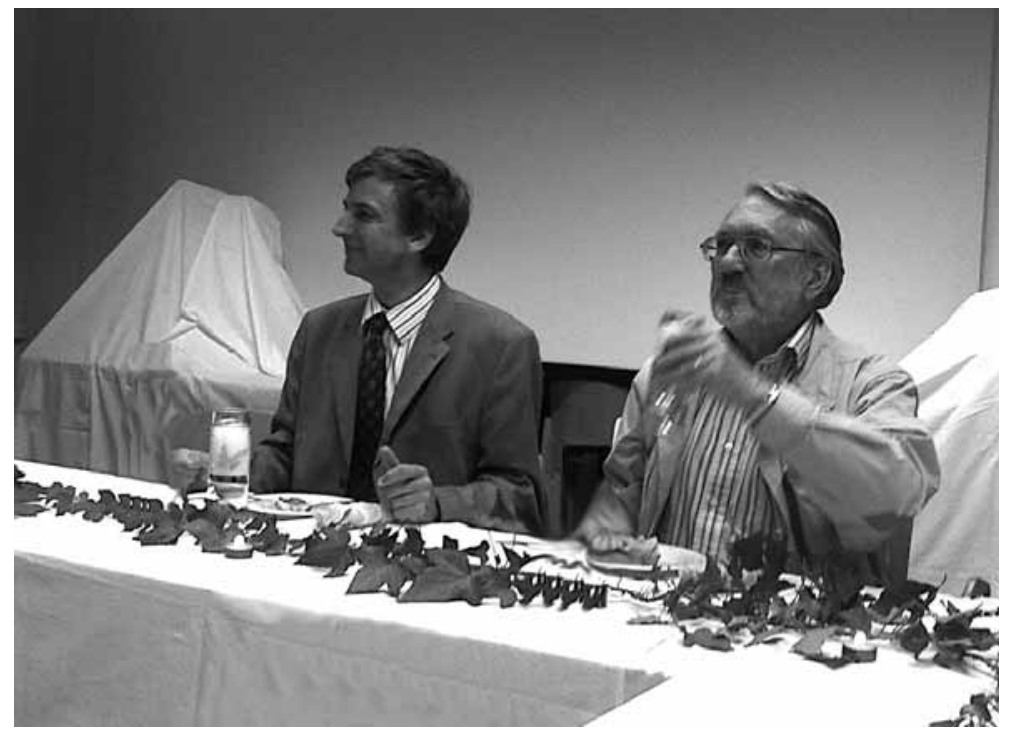

O. Koudelka and W. W. Weiss inaugurating the workshop dinner at the Institute of Astronomy. 


\section{Engineering}


